\title{
Spiritual Synchronicity: Icon Veneration in Evangelical and Orthodox Religious Practices in the 21st Century
}

\author{
Mae Elise Cannon and Kevin Vollrath *
}

Citation: Cannon, Mae Elise, and Kevin Vollrath. 2021. Spiritual Synchronicity: Icon Veneration in Evangelical and Orthodox Religious Practices in the 21st Century. Religions 12: 463. https://doi.org/10.3390/ rel12070463

Academic Editors: Bradley Nassif and Tim Grass

Received: 30 April 2021

Accepted: 22 June 2021

Published: 24 June 2021

Publisher's Note: MDPI stays neutra with regard to jurisdictional claims in published maps and institutional affiliations.

Copyright: (c) 2021 by the authors. Licensee MDPI, Basel, Switzerland. This article is an open access article distributed under the terms and conditions of the Creative Commons Attribution (CC BY) license (https:// creativecommons.org/licenses/by/ $4.0 /)$.
Churches for Middle East Peace (CMEP), Washington, DC 20002, USA; mae@cmep.org

* Correspondence: kevin@cmep.org

\begin{abstract}
Much scholarship in the dialogue between evangelical and Orthodox believers focuses on doctrinal compatibility. This article contributes to that literature by giving an example of a spiritual practice (icon veneration) that creates additional space for ecumenical dialogue and unity. Some USevangelicals in the 21st century have incorporated the use of icons into their personal faith practices. Icon veneration is ripe with ecumenical potential for evangelical-Orthodox relations because of its prominence in Orthodox communions while at the same time appealing to a growing number of evangelicals. This article considers three sites of evangelical icon use in turn: the Evangelical Baptist Church of Georgia (EBCG), Icons of Black Saints, and an evangelical ministry called "Heart of the Artist". Each site adopts a slightly unique understanding of icons that may appeal to evangelical believers. Although Orthodox and evangelical believers may understand theologies of icon veneration differently, the emergence of icon veneration among evangelicals remains a spiritual synchronicity, and ought to be recognized as such. Evangelicals continue to receive the gift of icon veneration from their Orthodox siblings in ways in line with the EBCG, Black Orthodox icons, and Heart of the Artist, so icon veneration has potential to further resource ecumenical dialogue.
\end{abstract}

Keywords: iconography; icon veneration; evangelical-Orthodox relations; ecumenism

\section{Introduction}

Often the history of different communions within the Christian church focuses on divisions rather than common practices, theological alignment, and harmony in worship. In the 21st century, there are many practices of the various Orthodox and evangelical spiritual traditions that are shared across the spectrum of Christian practice. ${ }^{1}$ These common practices represent what may be understood as a synchronistic unity between Orthodox and evangelical traditions. Events or practices are "synchronistic" in this sense if they occur simultaneously despite different origins or meanings. Synchronicity is therefore distinct from unity and uniformity.

This article focuses on one specific common spiritual practice: icon veneration. Evangelical and Orthodox icon uses have different origins and vary in diverse theological understanding of icons, and each tradition is also internally diverse. Still, evangelical and Orthodox icon use share a praxis in the context of worship and therefore have a synchronistic unity.

This article argues that icon veneration has untapped ecumenical potential for building rapport and authentic fellowship opportunities within evangelical-Orthodox relationships, specifically as evangelicals receive the "gift" of icon veneration from the Orthodox tradition. Catholic Ecumenist Marie Farrell argues that ecumenism is best practiced as "an exchange of gifts, where each tradition maintains its integrity but receives the best of others" (Farrell 2014, pp. 2-7). This article uses Farrell's understanding of ecumenism as a lens to describe one aspect of dialogue between evangelical and Orthodox believers: Icon veneration is a gift of the Orthodox tradition that can benefit evangelicals. In order to evidence this thesis, the article covers three contemporary and constructive appropriations of the gift of icons: 
the Evangelical Baptist Church of the Republic of Georgia (EBCG), ${ }^{2}$ African American Orthodox believers and the contemporary writing of icons of Black saints, and evangelical worship endorsed by leaders like Rory Noland and his ministry Heart of the Artist. In each of these examples, evangelicals receive the gift of icon veneration, and by modifying the tradition to their own context, participate in synchronistic unity with the Orthodox Church.

Though tangential to our main argument, it is worth noting that the Orthodox mission also benefits from this exchange. Evangelical icon veneration increases the scope and influence of Orthodox teaching as many evangelicals turn to Orthodox communions for instructions. The Orthodox Church's mission is broadened by others learning from their traditions, even when it is modified. For example, the veneration and recognition of Black saints through icons, discussed below in Section 4, enriches the diversity of icons. Important to Farrell's conception of ecumenism is mutual exchange between traditions; however, this article focuses specifically on what evangelicals might receive from Orthodox believers' veneration and use of icons.

Before overviewing the history of icon veneration and analyzing three case studies of contemporary icon veneration, it is important to note other scholars and pastors who argue for the ecumenical power of icons. Hilda Kleiman, for example, establishes the ecumenical significance of icons for Catholic-Orthodox relations in The Ecumenical Work of the Icon: Bringing the Iconographic Tradition to Catholic Seminaries. She offers a Catholic perspective on icon use and encourages Catholics to venerate icons and appreciate their beauty (Kleiman 2018). In addition to Catholic engagement with icons, some pastors and leaders in Mainline Protestant denominations have incorporated the veneration of icons in their worship experiences. ${ }^{3}$ Some Lutheran churches in the United States have benefited from adopting icon veneration as an essential component of their worship experience (Jensen 2001). For example, Jordan Cooper, pastor of Faith Lutheran Church in Watseka, Illinois, writes about why Lutherans might use the crucifix and icons to enhance their spiritual life (Cooper 2014):

"We use them as tools to instruct and remind us of our faith. The crucifix is a constant reminder of the gospel. It is often placed in the sanctuary to remind both the pastor and the congregation that Christ, and his cross are the center of the church's worship life. We use images of saints to remind us of the great faith of those who have come before us, and remind us of the unity of the church in heaven and on earth."

As in some Lutheran congregations, a small group of evangelicals already venerate icons and encourage others to do the same, although there is little, if any, sustained academic treatment of the subject of evangelical use of icons.

This article is a small part of a much larger dialogue between evangelical and Orthodox believers, which tends to focus more on doctrinal compatibility than spiritual practices. Tim Grass argues that ecumenical dialogue ought to be relational and spiritual in nature. Icon use is a spiritual practice that can create more space for this type of exchange (Grass 2010, pp. 194-95). Three Views on Eastern Orthodoxy and Evangelicalism shows the breadth of perspectives on this dialogue. Bradley Nassif, professor of biblical and theological studies at North Park University, defends the compatibility of Orthodoxy and Evangelicalism and aims to help the "Orthodox and evangelical worlds believe more positively about and act more constructively toward each other than they have to date," specifically for evangelicals to "reassess the comprehensiveness of their own incarnational Trinitarian faith" (Stamoolis 2004, p. 16). This article hopes to contribute to reflection on evangelical-Orthodox dialogue by considering the practice of icon veneration, even if doctrinal analysis will vary between Orthodox and evangelical believers, and even though icon veneration has been a point of tension historically between evangelical and Orthodox believers (Stamoolis 2004, p. 10). However, doctrinal disputes abound, so this article will continue by briefly describing the historical context of the controversies between iconoclasts and iconophiles, the significance of icons to the Orthodox tradition, and contemporary evangelical reflections on icon use. 
While not all evangelicals support icon veneration, those who do remain squarely within the evangelical tradition. ${ }^{4}$

\section{Icons and Iconoclasm}

Prior to delving more deeply into specific practices of icon veneration, it is helpful to understand the context and history of the use of icons. Both the Orthodox and evangelical traditions to some extent view early church practices as normative for the contemporary church, so the historical iconoclastic arguments help give voice to contemporary evangelical debates over icons. "Icon" is the transliteration of the Greek word for "image". An icon is "a sign of the presence of God," and typically depicts a saint, biblical scene, or Jesus (Tradigo 2006, p. 6). Icons vary in size and location, from the iconostasis, which separates the nave from sanctuary in Eastern Orthodox churches to placement on the nightstand of an Orthodox believer. They are generally painted on wood and only use materials directly found in nature. Alfredo Tradigo, scholar of Christian iconography, argues that "The very materials the icons are made of are important: a carved wood panel covered with layers of gesso, glue, and canvas; colors made of vegetable and mineral pigments; water and egg yolk; and gold leaf. They all appear as elements of the sacred ritual" (Tradigo 2006, p. 7). As Orthodoxy Scholar and iconographer Mariamna Fortounatto and Byzantine specialist Mary Cunningham describe the process, "The icon painter 'frees' matter as he [sic] offers it back to God in his [sic] reverent creation of an image" (Fortounatto and Cunningham 2008, p. 136). Iconographic styles vary, but all require their painter's rigorous attention and prayerfulness. The painting is an act of worship just like the eventual veneration. ${ }^{5}$

The church has deliberated and engaged in theological discourse about the permissibility and benefit of using imagery and icons in worship from its very conception. Initial prohibitions on the use of icons and imagery based their restrictions on the second of the Ten Commandments found in Exodus 20: 4-6 (NIV):

"You shall not make for yourself an image in the form of anything in heaven above or on the earth beneath or in the waters below. You shall not bow down to them or worship them; for I, the Lord your God, am a jealous God, punishing the children for the sin of the parents to the third and fourth generation of those who hate me, but showing love to a thousand generations of those who love me and keep my commandments."

Yet many in the early church viewed icons as representations of the living Christ as first exemplified through the Mandylion, a cloth imprinted with Jesus' face, understood to be the first icon and not made by human hands (Fortounatto and Cunningham 2008, p. 141). No examples of icons as they are known today survive from before the third century of Christianity, though many Orthodox believers claim they have always been present (Fortounatto and Cunningham 2008, p. 137).

Icon veneration has been formally recognized by the Orthodox church since the Seventh Ecumenical council in $787 \mathrm{CE}$, which distinguished between respect and veneration (timètike proskunessis, which can and ought to be given to icons) and true adoration (latrēia, which God alone merits, (Bulgakov 1931, pp. 1-2). Scholars debate when believers first painted and venerated icons, but many in the Eastern Orthodox and Roman Catholic traditions credit St. Luke as the first iconographer, writing an icon of the Virgin Mary holding the infant Jesus (Apostle and Evangelist Luke 2021). The early church historian Eusebius documents icon veneration as early as the fourth century CE (Eusebius 1890). It was not until the eighth century, though, that iconoclasm (opposition to icon veneration) gained government support when Byzantine Emperor Leo III issued multiple edicts condemning icon use (Treadgold 1997, pp. 350, 352-53).

One of the greatest debates about the question of the use of imagery and icons occurred during the eighth century in the Byzantine church between the iconoclasts and the iconophiles. Iconoclasts rejected and called for the destruction of religious images, whereas, iconophiles esteemed religious imagery as a reflection of the incarnational reality of Christ. According to Kenneth Parry in his book Depicting the Word: "Whereas the iconoclasts 
regard Christian images as being no better than pagan idols, the iconophiles endeavor to distinguish their own images from those of the pagans" (Parry 1996, p. 44).

Saint John of Damascus wrote three treatises On the Divine Images as a rejection of iconoclasm citing Exodus 25: 18-20 regarding the decoration of the tabernacle, "And make two cherubim out of hammered gold ..." (25: 18). St. John of Damascus argued the Incarnation itself is a kind of depiction of God as an image, thus the creation and use of icons must be permissible in Christian worship. Representing the perspective of the iconophiles, he offered a critique of the iconoclasts going so far as claiming they denied "the reality of Christ's human Incarnation" (Fortounatto and Cunningham 2008, p. 140). In defense of icon veneration, he argued that honoring an image is a form of honoring the person portrayed in that image, not the image as an end in itself (St. John of Damascus 2015).

The creation of icons comes from the Greek word grapho which more often denotes "painted" than "written," though sometimes the latter (Yiannias 2010). Dr. John Yiannias delivered a talk at the Orthodox Theological Society in America meeting in Chicago, Illinois, in 2008 and explained why it is important to not use the term "written" in referring to the creation of icons. He argued, God is "uncircumscribable [sic], unbounded, undepictable, incomprehensible, unsusceptible to containment within the boundaries that we must impose on anything before we can comprehend or speak of it" (Yiannias 2010). Thus, for Yiannias, the pictorial representations of icons must be understood theologically as conveying the greater act of sacredness in the production of the icon.

For evangelicals, and Protestants in general, there are several reasons for the lack of comfort with the veneration of icons including: fear their use is heretical and idolatrous, historical debate about their use in the context of the early church, and an unfamiliarity with the lives and contributions of the saints. Some early Protestant leaders such as John Calvin rejected the use of icons, and any form of imagery, claiming the omniscient and transcendent God is unknowable and beyond human comprehension. Other protestant leaders such as Luther accepted icon veneration, comparing it to the mental picturing of Jesus (Dorner 1871, vol. 1, p. 146). Thus, human attempts to paint, illustrate, and represent God will inherently be inadequate and will misrepresent the truth of his full revelation and divinity (Arakaki 2011).

Contemporary evangelicals debate whether the Incarnation of God in Jesus licenses icon veneration. Matthew Milliner, professor of Art History at Wheaton College disagrees, and asserts, God "depicted himself [sic] in the Incarnation, enabling us to, in turn, depict him [sic]" (Milliner 2010). Orthodox priest and professor at Duke Divinity School Edward Rommen concurs that "theologically, the church's teaching on images is grounded in the doctrine of the incarnation. God himself gave us an icon of himself in Christ and thereby, at least in principle, sanctioned the use of such imaging" (Rommen 2004, pp. 240-41). By contrast, Michael Horton, theology professor at Westminster Seminary California, infers from the Incarnation "precisely the opposite conclusion," namely, that Jesus "alone is God's univocal, if paradoxical, presence in flesh. The Reformed, therefore, are concerned that some Orthodox approaches to this question - and aspects of its liturgy that follow from them [including the use of icons] — reflect an under realized eschatology, living in the types and shadows while the Reality has come" (Horton 2004, p. 256). Thus, evangelicals work from similar sources of authority (the Incarnation) to ground their approach to icons.

A second reason for the resistance of evangelical engagement with icons has to do with the historical debate about how prevalent, if at all, they were used in the practice of worship by the early church. For example, the Gospel Coalition, a network of broadly Reformed evangelical churches, contends that icon veneration was not practiced in the early church and rather, "the archeological evidence gives us some examples of Christian imagery but not necessarily in places of worship and... there is no evidence that it ever went beyond decorations. The actual writings of the early church leaders are consistently opposed to the dangers of iconography" (Carpenter 2021). Nonetheless, other evangelical 
leaders like Ed Stetzer of Wheaton College disagree and identify the practice of veneration within Eastern Orthodoxy as in "continuity with the early church" (Stetzer 2017).

Finally, evangelical and Protestant Christians do not formally venerate saints and thus imagery representing historical Christians who have been canonized is outside of traditional forms of worship, prayer, and the experience of the majority of Protestant Christians, including evangelicals. ${ }^{6}$ Nonetheless, increasingly in the twentieth century, bridges are starting to be built with evangelical congregations and communities who have been exposed to the formal veneration of icons. More and more evangelical and other Protestant religious leaders and academics are seemingly shedding historic concern about the legitimacy of icons and instead claiming the veneration of icons as a constructive, legitimate form of worship. See, for example, the evangelical leaders from The Transforming Center and Rory Noland, of Heart of the Artist Ministries, discussed below and the Evangelical Baptist Church of Georgia. ${ }^{7}$

\section{Evangelical Baptist Church of Georgia (EBCG)}

Rev. Dr. Malkhaz Songulashvili serves as the Metropolitan Bishop of the Evangelical Baptist Church of the Republic of Georgia and widely uses the veneration of icons in the context of worship. The Evangelical Baptist Church of Georgia was founded in 1867 by Protestant Orthodox believers in Tbilisi, Georgia, over 150 years ago, because of theological dialogue and discussion among Orthodox dissidents (Songulashvili 2020). Bishop Songulashvili identifies himself and the church as a part of the Orthodox communion because of culture, liturgy, theology, and aesthetics; but he also shares some beliefs from the Radical Reformation which include believer's baptism, the significance of the Bible, and other secondary considerations like the separation of church and state. He believes the use of icons is an example of the synchronicity of orthodox practice and evangelical theological foundations because it represents the "natural amalgamation of the two traditions, both deeply rooted in the Gospel tradition" (Songulashvili 2020). Evangelicals come to icon veneration over decades, compared to the centuries over which the Orthodox Church has practiced and refined this spiritual practice, making the practice synchronous between evangelicals and Orthodox believers. Bishop Songulashvili further asserts the use of Orthodox liturgy represents the "ecumenical hospitality" and shared gifts between the Orthodox and evangelical traditions. While acknowledging differences with the Orthodox tradition, Bishop Malkhaz writes "that traditionally Orthodox Georgian culture could be an ally in [its] mission and not its foe" (Songulashvili 2015, p. 314). The ECBG claims to have been long receiving and combining the gifts of many traditions (Songulashvili 2015, p. 314).

This article intentionally does not take a stand on the controversy regarding the EBCG and its relationship to Orthodox communions. As a minority tradition within a mostly Orthodox country, it is important to voice their perspective as judiciously as possible. The authors do not wish to suggest anyone congregation separate from the Orthodox communion, or any communion. On the contrary, veneration of icons is a practice which can bring together traditions otherwise separated. Please see the appendices of Evangelical Christian Baptists of Georgia for more details. ${ }^{8}$

The Metropolitan Bishop asserts that Christians must learn to respect the integrity of other traditions and should "shift from proselytism to learning from others," adopting a missiological paradigm for the future that will allow for more shared practices and common fellowship (Songulashvili 2020). For example, Bishop Songulashvili practices an old Byzantine style of iconography and believes anyone who made a "big contribution to the Kingdom of God or to the implementation of the Mission of God" can be canonized and iconized. He cited as examples Martin Luther King, Jr.; the Sufi monastic, Jareda Rumi; and the Roman Catholic Mother Teresa as significant seekers of the justice and peace movement who helped further kingdom principles here on earth. Sainthood, for Bishop Songulashvili, is not about perfection, but rather "setting an example and encouragement to us in our attempts to follow Jesus". He continued, "God works through those created in his or her image, regardless of nationality, tribe, or religion" (Songulashvili 2020). This 
does not imply universalism or negate the need for personal salvation, but is rather an understanding of God's love for all who bear the imago dei.

Bishop Songulashvili and his congregation do not identify as belonging solely to either the Orthodox communions, or evangelical churches. He claims that their practice of worship and ecumenicism is often "equally unacceptable" to both Orthodox and evangelical believers, but he believes that uniquely positions his church to be a witness to the mission of God's kingdom to both communities. He does this by remaining committed to working alongside churches and other Christian groups throughout Georgia including congregations within the Ukrainian Orthodox communion, despite disagreeing with some aspects of Orthodox and evangelical worship. As exemplified in their contemporary use of icons, the Bishop affirms his mission to "build bridges" between Jews, Muslims, and Yazedis and all people as an expression of the Christian faith. ${ }^{9}$

\section{Icons of Black Saints}

The use of icons by people of African descent extends beyond the traditional practices of African Orthodox church communities and includes viewing icons as symbolic representations of the liberating power of faith in Christ Jesus for Black people. According to the Cambridge Companion to Orthodox Christian Theology, "The challenge for the iconographer is to paint human beings who already in their earthly lives have passed beyond the threshold of the Kingdom [sic]. The saints' experience of the divine must be translated so that the beholder may contemplate the Kingdom through the icon and acquire sanctification through the grace of the Holy Spirit, fulfilling what all God's creation is called to become" (Fortounatto and Cunningham 2008, p. 142). This transcendence takes on a unique meaning for Black Orthodox Christians who use icons that demonstrate African people and Black Americans as saints and elevate the roles of how African women contributed significantly to the history of Christianity. The use of Black icons, sometimes depicting African American heroes of the Civil Rights Movement, also might appeal to Black Christians from other traditions outside of the Orthodox Church. In addition, the painting of black icons cannot be considered appropriation, as many of the artists who paint Black saints are often members of The African Orthodox Church (AOC).

While this section focuses on icons of Black saints written in the Orthodox Church, many evangelicals share the same concerns that motivate the writing of these icons: a desire for spiritual nourishment, tangible connection between justice and worship, and anti-racist spiritual resources. Insofar as (some) evangelicals have these concerns, they may be drawn to venerate Black saints, thus sharing synchronistically in icon veneration with the $\mathrm{AOC}$ and other Orthodox believers venerating Black saints. ${ }^{10}$

The AOC has aimed since their founding in 1921 to address racial discrimination in the United States with the help of the Orthodox tradition. The AOC has always been committed to maintaining Black leadership on all levels, also mandating that Jesus be depicted as African. The AOC adopts icon veneration to these goals by canonizing and making icons of "modern-day saints as Martin Luther King, Marcus Garvey, the church's founder Alexander McGuire, and John Coltrane" (Kravchenko 2020, p. 90).

Elena Kravchenko writes in “Black Orthodox 'Visual Piety': People, Saints, and Icons in Pursuit of Reconciliation," "People of African descent had to take their rightful placeideally, but first materially - within the broader worldwide Christian community of saintly figures" (Kravchenko 2020, p. 87). The use of black icons not only benefits the experience of African Orthodox worshipers, but has positive impacts on the broader community of Christians by aiding evangelism, promoting anti-racism, and aiding black identity formation in ways that help to cultivate virtue.

According to Kravechenko, the use of black icons represents the Christian community to people of color as "truly inclusive" and offers an invitation for non-believers to experience conversion and become a part of the community of believers. She asserts that evangelicals, and anyone interested in cultivating virtuous religious identity, would do well to venerate icons (Kravchenko 2020, p. 97). A practitioner named Michael affirms 
the power of black icons and their evangelistic significance in his own narrative. He says, "Although I have appreciated the love the white brothers and sisters have given me, for a Black man to receive the faith from Black fathers is very powerful. In this way, I have come into Orthodoxy", Michael notes. "So many things have been answered for me-the Blackness, my Blackness, is finally being shown to me. Even though I always knew it was there, I never knew how it connected. Finally, somebody is not denying the fact that we exist, that we are part of God's family and purpose, and I needed that". He concluded, "When I come into the church, and I see the icons ... I no longer see this white-skinned, blue-eyed Jesus that I grew up seeing... Then, to read about all the different saints and get the whole story and receive the tradition from the time of the Apostles has been powerful!" (Kravchenko 2020, p. 99).

Ethnically diverse icons are not new to the 21st century. D. Oliver Herbel, Orthodox priest and independent scholar, argues in Turning to Tradition: Converts and the Making of an American Orthodox Church that icons of St. Moses the Black in particular have been moving for Black believers (Herbel 2014, p. 91). Moses the Black was a fourth-century Ethiopian monk living in Egypt, honored as a Desert Father, depicted with black skin in icons. Herbel quotes Fr. Moses Berry, a contemporary Black Orthodox priest, arguing that "the tradition of the evangelist Matthew's proselytizing in Africa, Athanasius the Great's consecration of Bishop Frumentius, and the presence of 'countless Black saints and martyrs' all pointed to the importance of saints of African descent"(Herbel 2014, p. 92). Albert Raboteau, author of Slave Religion: The "Invisible Institution" in the Antebellum South and celebrated scholar of American religious history, compares his experience venerating Orthodox icons to his experience of slave spirituals, "overwhelmed by the spiritual power" of both (Raboteau 2002, p. 42). Raboteau details convergences between Orthodox spirituality and African American slave religion other than icon veneration in his afterword to An Unbroken Circle: Linking Ancient African Christianity to the African-American Experience (Raboteau 1997).

The use of black icons can also be a tool in aiding anti-racism efforts by providing powerful visual representations of black saints as good, holy, and connected to the divine. The power of marginalized people being represented in icons cannot be underestimated. Not only does the painting of black historic figures and women tell black people they too might attain saintly behavior and live out their faith in practice, but Kravchenko also gives reasons why any non-Orthodox believers might appreciate icon veneration. For example, black icon veneration helps white Americans "see African saints in order to think of and treat Black people as capable of saintly actions" (Raboteau 1997, p. 100). In this way, black icon veneration aids black identity formation and can also help to cultivate virtue.

Finally, white people can also reap the benefits of the veneration of icons of black historical figures. The painting of African American and African saints invites white people to resist their own internal prejudices and internalized racism and to experience fellowship with African American siblings who have fought for integration and against white supremacy, which ultimately contributes to the degradation of the souls of white people (Cone 1997, pp. 216-17). Kravchenko's descriptions of the use of icons in the African American community demonstrates how they are a blessing to those who venerate the icons and also the potential black icons have to build bridges across both ecumenical and racial divides.

\section{Rory Noland and 'Heart of the Artist'}

The veneration of icons outside of the Orthodox community and particularly by evangelicals presents one of the most significant opportunities for ecumical unity and bridge building between Orthodox and evangelical communities. This is exemplified in the ministry and teaching of Rory Noland, founder of Heart of the Artist Ministries.

Rory Noland represents one of the most significant educators of evangelical worship with a background in pastoral leadership at Willow Creek Community Church (WCCC) one of the most influential evangelical megachurches in the United States. He has published several books with the evangelical publisher Zondervan and uses icons both in his own 
worship experience and in his teaching. For Noland, the veneration of icons are valuable for evangelicals in that they provide an invitation and opportunity for prayer. They draw believers toward the sacred and help evangelicals expand their understanding of worship.

Noland researched and began to embrace the use of icons in worship as a part of his research and writing for his foundational theology of worship in the book project Heart of the Artist. In addition to his personal use and writing, he teaches a session on the use of icons for The Transforming Center cohorts which predominantly include Protestant and evangelical pastors and Christian leaders (Noland 2021). ${ }^{11}$ In addition, The Transforming Center has had a longstanding relationship with Northern Theological Seminary which is an evangelical academic institution connected to the American Baptist Churches USA. ${ }^{12}$

Over the course of his research and personal practice, Noland has visited Orthodox churches around the world, including in the United States, Romania, and Russia. His discovery of Orthodox icon veneration prior to major experience in the Orthodox tradition is synchronistic with Orthodox iconography: the practice is shared between the traditions but each tradition has a distinct timeline. While Rory, like many evangelicals, has a limited relationship with the Orthodox Church, his use of icons demonstrates their potential as a source of evangelical-Orthodox dialogue. The following discussion of Rory's views on and uses of icons serves to demonstrate how some evangelicals may conceive of icons for worship. This may encourage non-venerating evangelicals to consider icon use and also begin a dialogue with Orthodox believers about evangelical icon use and theology.

According to Noland, one of the first challenges for evangelicals includes a lack of understanding and theological context for how icons might be used in worship. Many evangelicals assume the use of icons means people are "worshiping the saints". Many evangelicals have suspicion of Catholic traditions and traditions of the Orthodox Church and assume they come from eastern traditions that are not rooted in Christianity. Ignorance of Orthodox traditions and lack of exposure to early church history contributes to these misconceptions. Rory Noland acknowledged that teaching people the "veneration of icons is not worshiping the saints" is one of the biggest challenges he faces in teaching about the use of icons to evangelicals. He experiences people often assuming that these are traditions of the East without understanding the significance of icons in the early church and how the use of icons flourished during the Byzantine Empire. Another challenge for many evangelicals, according to Noland, is that many come from Catholic backgrounds and have concerns that icon veneration reminds them of early church experiences they have tried to leave behind. Noland begins by assuring his students that the veneration of icons has its roots in early Christianity. He encourages people to step out of their comfort zone and to explore the use of icons in worship as a means of trying to get people to step "outside of their box" and to better understand traditions with which they may not be familiar or comfortable (Noland 2021).

For Noland, icons can constructively serve as a tool for prayer. He explains to evangelicals what it means to venerate icons, by showing them respect and honoring them, does not mean worshiping them. Icons bring people deeper into prayer. Noland describes, "When you sit before an icon, when you realize and point out the differences between an icon and a regular painting... [the icon] causes you to think because it expresses theological truth in a highly stylized and visual language" (Noland 2021). One has to learn how to use icons in the context of prayer and to "learn the language" of what the icon can teach and expose as one seeks to experience intimacy with the Creator. Noland continues, "Sitting in front of an icon is different than sitting in front of other art forms. You are drawn into the picture ... into the scene, the theology of it". He describes the Trinity icon as a perfect example. He does not instruct people to sit in front of icons for hours, but rather to use icons as a "springboard for prayer" to help focus and not get distracted and to use the icon to draw one back into a posture of prayer. For evangelicals, the use of icons must be "very practical" so Noland attempts to provide practical ways for icons to be used in prayer and worship, trying to minimize apprehension, without taking the mystery out of the experience of icon veneration (Noland 2021). 
Rory Noland believes icons work together with other aspects of the worship experience and "draw us toward the sacred". The sermon brings the power of the Word of God. The experience of the Eucharist and the Table bring an embodied experience of tasting and being welcomed into the mystery of communion. Icons, for Noland, access both the "head and the heart" which serves as a springboard for prayer and "bids you to linger in it" and to let go and invite God "deeper into your heart". The veneration of icons does not just incorporate head knowledge but "heartfelt knowledge that invites us into the presence of God". This is the beauty of the icon experience (Noland 2021). The power of the visual is that a deep theological truth is being communicated that you will never forget because the image will stay with you and when it is used time and time again will remind the participant of previous experiences.

Many evangelicals have limited and simplistic understandings of multifaceted aspects of worship and consider singing hymns and songs as the most common and significant form of worship. One of Noland's goals through Heart of the Artist Ministries is to expand evangelical understandings of worship to include diverse and creative use of many forms of art and spiritual practice beyond just that of music. He writes about how worship is a pathway for experiencing and encountering the divine in his book Worship on Earth as it is in Heaven: Exploring Worship as a Spiritual Discipline. For Noland, worship is very much about corporate prayer, the Word, the sacrament of the eucharist, and other forms of art that lead us into God's presence. Noland describes how icons introduce us and open us up to the sacred, he says, "That is the beauty of it. One thing I know, all Christians, all people whatever church they are from, whatever religion they may be, have a burning in their heart for the sacred because that represents our yearning for God and opens us up to the sacred". Noland's integration of icons exemplifies how evangelicals benefit from historic icon veneration that is so integral in Orthodox religious practice, thus sharing the practice synchronistically.

\section{Conclusions}

Icon veneration is ripe for ecumenical dialogue. The ECBG is a paradigmatic example of a bridge-building community, connecting evangelicals/baptists and Orthodox believers. Veneration of Black saints through icons is another place evangelicals and Orthodox believers committed to anti-racism can come together around common practices of worship. Rory Noland and his following exemplify how evangelicals might appropriate icon veneration for their own interests in spiritual growth, potentially leading them to want to learn more from the Orthodox traditions.

Evangelicals and others in the broader ecumenical community have much to learn and benefit from the veneration of icons as exemplified by Rory Noland and Heart of the Artist Ministries, the use of black icons as a mechanism of elevating historically marginalized people, and in the worship and experience of the Evangelical Baptist Church of the Republic of Georgia. From Bishop Songulashvili, the use of icons is one manifestation of what it means to live in harmony with Orthodox neighbors while practicing the Orthodox liturgy, holding onto evangelical theological beliefs, and also engaging in progressive social action. The painting of African American icons helps shed light on historic racial injustices and to invite evangelicals, white people, and others to esteem black Christians as saints of the church and a critical and essential part of the beloved community of the body of Christ. Finally, Rory Noland teaches how evangelicals and others are invited into prayer and drawn into the presence and experience of the sacred through the use of icons in the context of worship.

It is the hope of these authors that these individual case studies provide evidence for how the Holy Spirit is sowing unity at the level of synchronicity though not uniformity, even as there remain divisions on specific theological interpretations and on the level of doctrine. Our hope is that there might be further synchronism between these groups of believers in order for the experiences of shared practice to continue to build bridges and promote unity across the spectrum of Christian communions and denominations. 
Author Contributions: M.E.C. and K.V. researched and discussed all elements of this article concurrently. Both authors have read and agreed to the published version of the manuscript.

Funding: This research received no external funding.

Acknowledgments: We would like to thank Danut Manastireanu, Rory Noland, Malkhaz Songulashvili for their helpful interviews.

Conflicts of Interest: The authors declare no conflict of interest.

\section{Notes}

1 For the purposes of this conversation, evangelicals might be understood using British historian David Bebbington's definition, Christians who are committed to biblicism, esteem for the Bible as Holy Scriptures inspired by God; crucicentrism, acknowledging the atoning work of Christ's death on the cross; conversionism, the necessity of being born again through belief into the body of Christ; and activism or mission, that the work of the church is the spreading of the Gospel into the world. See (Bebbington 1989, pp. 2-17). For the purposes of this article, Orthodox traditions refers specifically to "the local Churches of the Eastern Roman empire, including Constantinople, Alexandria, Antioch and Jerusalem, as well as the Churches that came into being as a result of their missions". See (Cunningham and Theokritoff 2008).

2 The EBCG has a complicated history detailed in Bishop Songulashvili's (2015). It emerged from dialogue between Orthodox believers taking a protestant turn and Baptists looking for deeper liturgy. This article includes the EBCG as an evangelical use of icons because it is an autocephalous church, meaning, it determines its own head and is not subject to an external patriarch. While many of its practices are Orthodox, it is not formally a member of any Eastern Orthodox communion. Though highly controversial, the ECBG is also a paradigmatic example of a bridge-building community, adopting practices from both Orthodox and broadly evangelical traditions.

3 Many Anglicans also incorporate icon veneration into their devotional practice. See, for example, Crane's (2020) and Archbishop Nicholls's (2021), and Goebel's (2017).

4 This article focuses on official Orthodox teaching about icons. Growing evangelical-Orthodox dialogue about social practices in general and icon veneration in particular could also come to include discussion of lay people's icon veneration, which may stray from official Orthodox doctrine or standard evangelical teachings. Evangelicals can "receive the gift" of icon veneration from lay people as well as official Orthodox teaching.

5 For two contemporary iconographic methods, see Saint Seraphim's Saint Seraphim's Trust's (2021) and Monastery Monastery Icon's (2021).

6 It may be interesting to compare formal evangelical icon veneration to the informal veneration paid evangelical saints and missionary heroes, but that is beyond the scope of this article.

7 See also Mathewes-Green's (2003), and Transforming Center's endorsement of it: https://resources.transformingcenter.org/ products/the-open-door-entering-the-sanctuary-of-icons-and-prayer (accessed on 5 January 2021).

8 See Songulashvili's (2015) appendices 8 and 11-15.

9 While it is beyond the scope of this article to give the full history of the EBCG's history even just in relation to icons, it is important to note that the church community plays an important role in their use of Orthodox practices in general and icon veneration in particular. See especially chapter 3 of Evangelical Christian Baptists of Georgia: The History and Transformation of a Free Church Tradition, "The Formation of the Georgian ECB's Institutional Identity (1942-1989)".

10 For further evidence of this, see Kelly Latimore, an evangelical producing diverse icons, and his store "Kelly Latimore Icons". See also (Lowes 2021).

11 Transforming Center: Strengthen the Soul of your Leadership, Homepage, https://transformingcenter.org/ (accessed on 5 January 2021).

12 See the American Baptist Churches USA homepage: https://www.abc-usa.org/ (accessed on 3 December 2020).

\section{References}

Apostle and Evangelist Luke. 2021. Orthodox Church in America. Available online: https://www.oca.org/saints/lives/2021/10/18/1 02993-apostle-and-evangelist-luke (accessed on 28 January 2021).

Arakaki, Robert. 2011. Calvin Versus The Icon: Was John Calvin Wrong? Orthodox-Reformed Bridge. June 19. Available online: https:/ / orthodoxbridge.com/2011/06/19/calvin-versus-the-icon/ (accessed on 15 October 2020).

Bebbington, David. 1989. Evangelicalism in Modern Britain: A History from the 1730s to the 1980s. London: Unwin Hyman.

Bulgakov, Sergei. 1931. The Icon and Its Veneration (A Dogmatic Essay). In Icons and the Name of God. Grand Rapids: William B. Eerdmans Publishing Company.

Carpenter, John. 2021. Answering Eastern Orthodox Apologists Regarding Icons. Themelios. vol. 43. Available online: https: / / www.thegospelcoalition.org/themelios/article/answering-eastern-orthodox-apologists-regarding-icons/ (accessed on 21 January 2021). 
Cone, James. 1997. God of the Oppressed. Maryknoll: Orbis Books.

Cooper, Jordan. 2014. Lutherans and the Use of Images. Patheos. June 3. Available online: https://www.patheos.com/blogs/ justandsinner/lutherans-and-the-use-of-images / (accessed on 15 October 2020).

Crane, Kate. 2020. How to Build a Prayer Corner-And Bring the Communion of Saints Home. Anglican Journal. March 26. Available online: https: / / www.anglicanjournal.com/how-to-build-prayer-corner-and-bring-the-communion-of-saints-home/ (accessed on 1 May 2021).

Cunningham, Mary B., and Elizabeth Theokritoff. 2008. Who are the Orthodox Christians? A historical introduction. In The Cambridge Companion to Orthodox Christian Theology. Cambridge Companions to Religion. Edited by Mary B. Cunningham and Elizabeth Theokritoff. Cambridge: Cambridge University Press.

Dorner, Isaak. 1871. History of Protestant Theology. Translated by George Robson, and Sophia Taylor. Edinburgh: T. \& T. Clark, vol. 1.

Eusebius. 1890. Ecclesiastical History. Edited by Philip Schaff and Henry Wace. Translated by Arthur Cushman McGiffert, Nicene, and Post-Nicene Fathers. A Text in the Public Domain Kindly Placed Online by Kevin Knight at New Advent. Second Series; Buffalo: Christian Literature Publishing Co., vol. 1. Available online: https://topostext.org/work/732 (accessed on 1 May 2021).

Farrell, Marie T. 2014. Ecumenism: Towards an 'Exchange of Gifts'. Compass 48: 2-7.

Fortounatto, Mariamna, and Mary B. Cunningham. 2008. Theology of the Icon. In The Cambridge Companion to Orthodox Christian Theology. Cambridge Companions to Religion. Edited by Mary B. Cunningham and Elizabeth Theokritoff. Cambridge: Cambridge University Press.

Goebel, Greg. 2017. Are Icons Okay to Use in Prayer and Worship? Anglican Compass. August 9. Available online: https:// anglicancompass.com/are-icons-okay-to-use-in-prayer-and-worship/ (accessed on 1 May 2021).

Grass, Tim. 2010. Dialogue between Evangelicals and Orthodox: Past, Present and Future. Transformation 27: 186-98. [CrossRef]

Herbel, Oliver. 2014. Turning to Tradition: Converts and the Making of an American Orthodox Church. New York: Oxford University Press.

Horton, Michael. 2004. Are Eastern Orthodoxy and Evangelicalism Compatible? No: An Evangelical Perspective. In Three Views on Eastern Orthodoxy and Evangelicalism. Counterpoints: Bible and Theology. Grand Rapids: Zondervan, pp. 89-96.

Jensen, Mary Elizabeth. 2001. A Journey of Transformation with the Holy Icons in Two Lutheran Congregations. Ph.D. thesis, Fuller Theological Seminary, Pasadena, CA, USA.

Kleiman, Hilda. 2018. The Ecumenical Work of the Icon: Bringing the Iconographic Tradition to Catholic Seminaries. Eugene: Wipf \& Stock.

Kravchenko, Elena. 2020. Black Orthodox 'Visual Piety': People, Saints, and Icons in Pursuit of Reconciliation. Journal of Africana Religions 8: 84-121. [CrossRef]

Lowes, Robert. 2021. Iconographer Kelly Latimore sees God in plain sight. Christan Century, April 26.

Mathewes-Green, Frederica. 2003. The Open Door: Entering the Sanctuary of Icons and Prayer. Brewster: Paraclete Press.

Milliner, Matthew. 2010. Sunday of Orthodoxy: Or, When Schisms Are Functionally Irrelevant. First Things. February 20. Available online: https:/ / www.firstthings.com/blogs/firstthoughts/2010/02/sunday-of-orthodoxy-or-when-schisms-are-functionallyirrelevant/ (accessed on 20 October 2020).

Monastery Icon. 2021. How an Icon Is Painted. Available online: https://www.monasteryicons.com/product/How-an-Icon-isPainted/did-you-know (accessed on 10 January 2021).

Nicholls, Archbishop Linda. 2021. Seeing God beyond Our Mirror Images. Anglican Journal. February 8. Available online: https: // www.anglicanjournal.com/seeing-god-beyond-our-mirror-images/ (accessed on 1 May 2021).

Noland, Rory. 2021. Evangelicals and Icons. Zoom Interview with Mae Cannon (Seattle, USA and Kevin Vollrath, Lambertville, USA). Virtual, January 8.

Parry, Kenneth. 1996. Depicting the Word: Byzantine Iconophile Thought of the Eighth and Ninth Centuries. Germany: E.J. Brill.

Raboteau, Albert. 1997. Afterword. In An Unbroken Circle: Linking Ancient African Christianity to the African-American Experience. Edited by Paisius Altschul. St. Louis: Brotherhood of St. Moses the Black.

Raboteau, Albert. 2002. A Sorrowful Joy. New York and Mahwah: Paulist Press.

Rommen, Edward. 2004. Are Eastern Orthodoxy and Evangelicalism Compatible? Maybe: An Orthodox Perspective. In Three Views on Eastern Orthodoxy and Evangelicalism. Counterpoints: Bible and Theology. Grand Rapids: Zondervan, pp. 155-57.

Saint Seraphim's Trust. 2021. How an Icon Is Made. Available online: https:/ /iconpainter.org.uk/about/iconography/icons/ (accessed on 10 January 2021).

Songulashvili, Malkhaz. 2015. Evangelical Christian Baptists of Georgia: The History and Transformation of a Free Church Tradition. Waco: Baylor University Press.

Songulashvili, Malkhaz. 2020. Bishop of the Evangelical Baptist Church of the Republic of Georgia. Zoom Interview with Kevin Vollrath (Lambertville, USA). December 13.

St. John of Damascus. 2015. St. John of Damascus on Holy Images. Translated by Mary H. Allies. London: Gutenberg, pp. 12-14. Available online: http:/ / www.gutenberg.org/files/49917/49917-h/49917-h.html (accessed on 30 November 2020).

Stamoolis, James J. 2004. Introduction. In Three Views on Eastern Orthodoxy and Evangelicalism. Edited by James J. Stamoolis. Grand Rapids: Zondervan.

Stetzer, Ed. 2017. Hank Hanegraaff's Switch to Eastern Orthodoxy, Why People Make Such Changes, and Four Ways Evangelicals Might Respond. Christianity Today. April 13. Available online: https:/ /www.christianitytoday.com/edstetzer/2017/april/howshould-we-respond-to-hank-hanegraaffs-switch-to-orthodo.html (accessed on 20 October 2020).

Tradigo, Alfredo. 2006. Icons and Saints of the Eastern Orthodox Church. Los Angeles: J. P. Getty Museum. 
Treadgold, Warren. 1997. A History of the Byzantine State and Society. Stanford: Stanford University Press.

Yiannias, John. 2010. Icons Are Not ‘Written'. Orthodox History. June 8. Available online: https://orthodoxhistory.org/2010/06/08 /icons-are-not-written/ (accessed on 20 October 2020). 